\title{
Compositional Variation of PCBs, PAHs, and OCPs at Gas Phase and Size Segregated Particle Phase during Dust Incursion from the Saharan Desert in the Northwestern Anatolian Peninsula
}

\author{
S. Levent Kuzu \\ Environmental Engineering Department, Civil Engineering Faculty, Yildiz Technical University, Davutpaşa, Esenler, \\ 34220 Istanbul, Turkey \\ Correspondence should be addressed to S. Levent Kuzu; skuzu@yildiz.edu.tr
}

Received 5 March 2016; Accepted 22 March 2016

Academic Editor: Pedro Salvador

Copyright (c) 2016 S. Levent Kuzu. This is an open access article distributed under the Creative Commons Attribution License, which permits unrestricted use, distribution, and reproduction in any medium, provided the original work is properly cited.

A dust incursion occurred in Istanbul on 1 February 2015 from the Saharan Desert. During this episode, $938 \mu \mathrm{g} \cdot \mathrm{m}^{-3}$ of TSP concentration was observed. TSP concentration was $64 \mu \mathrm{g} \cdot \mathrm{m}^{-3}$ and $78 \mu \mathrm{g} \cdot \mathrm{m}^{-3}$ on the following two days. Particles of $3 \mu \mathrm{m}$ were dominant during the episode; however, particles $<0.49 \mu \mathrm{m}$ were dominant after the episode. The averages of total (gas + particle) PCB, PAH, and OCP concentrations were $279 \mathrm{pg} \cdot \mathrm{m}^{-3}, 175 \mathrm{ng} \cdot \mathrm{m}^{-3}$, and $589 \mathrm{pg} \cdot \mathrm{m}^{-3}$, respectively. Tri-CBs were dominant in most of the samples. Flt and Phe had the highest contribution to PAH species. $\beta-\mathrm{HCH}$ and heptachlor had the highest share in terms of OCPs. Particle phase PCBs exhibited monomodal size distribution, whereas OCPs had bimodal size distribution. PAHs exhibited either monomodal or bimodal size distribution on different days. The mass median diameter of PAHs did not change significantly during different atmospheric conditions due to their local sources. Gas/particle partitioning of each pollutant was evaluated by plotting their subcooled vapor pressure against the partitioning coefficient. From 1 to 3 February, the slope of the regression line shifted close to -1 , indicating that the least favorable conditions were present during dust incursion for an equilibrium state.

\section{Introduction}

Several epidemiological studies revealed that particulate matter (PM) is an important cause of respiratory, cardiovascular, allergic, and lung cancer diseases $[1,2]$ and is reported to lead an increase in mortality $[3,4]$. Some studies relate $\mathrm{PM}_{2.5}$ exposure and increased mortality [5-7]. Health effects that are related to PM depend on their characteristics such as concentration, size, and their chemical composition $[8,9]$. Therefore, monitoring such characteristic properties of PM is essential to understand their effects, sources, formation, removal, and transformation mechanisms in the atmosphere [10]. From this perspective, the most important data about $\mathrm{PM}$ is its size distribution, which provides information about their sources, formation processes, and the transformation processes during atmospheric transport [11]. Atmospheric particles can be classified into three major groups as $D_{p}<$ $0.1 \mu \mathrm{m}, 0.1 \mu \mathrm{m}<D_{p}<2.5 \mu \mathrm{m}$, and $D_{p}>2.5 \mu \mathrm{m}$ according to their sizes [12]. Each of these sizes has different sources. Ultrafine particles occur through combustion processes or are generated through homogenous nucleation; accumulation mode particles are formed by the growth of ultrafine particles; and coarse particles are formed by mechanical processes [12].

Polychlorinated biphenyls (PCBs), polycyclic aromatic hydrocarbons (PAHs), and organochlorinated pesticides (OCPs) are classified as semivolatile organic compounds (SVOCs). The vapor pressure of SVOCs varies between $10^{-4}$ and $10^{-11} \mathrm{~atm}$ [13]. PCBs and OCPs are also among the group of persistent organic pollutants (POPs). These pollutants are listed as POPs due to their high toxicity, prolonged persistence over time in the environment, and 
carcinogenic/mutagenic effects [14]. PCBs were commercially produced and used for approximately 50 years. Their historical global production estimation is approximately 1.3 million tons [15]. Although intentional PCB production is not present anymore, they are still released from previously contaminated sites and industrial activities. Several studies indicate that in particular thermal industrial processes cause PCB releases into the atmosphere [16-18]. OCPs were applied to agricultural product protection against insects, herbs, and fungi. Some amount of the applied OCP fraction is emitted to the atmosphere [19]. Although OCPs are banned, they are still detected in different environmental mediums [20]. Their persistent structure and evaporation from previously contaminated sites result in their detection. PAHs constitute some of the organic fraction of PM [21] and are formed during the incomplete combustion of organic materials. Therefore, they can be emitted from various sources. The most significant sources of PAHs in the urban atmosphere are motor vehicles [12]. The size distribution data of PAHs in the urban atmosphere provides critical data of their transport and fate [22]. Either SVOCs or POPs can be transported over great distances due to their volatility and persistent existence in the atmosphere [23].

Istanbul is located between the continents of Asia and Europe and is a common route for air masses transported between these continents [24]. If air flows from east of the Carpathian Mountains channels over the Black Sea to the Aegean Sea, air masses from European countries arrive in Istanbul [25]. From time to time, different air mass transportation route from the Saharan Region of North Africa to Istanbul is formed. In the winter and in spring, dust outbreaks are observed at Istanbul [26-28]. In this study, air sampling was conducted in Istanbul during a Saharan dust incursion event. The primary aims of this study were to characterize (i) ambient aerosol size distribution, (ii) $\mathrm{PCB}, \mathrm{PAH}$, and OCP particle size distribution, and (iii) gas/particle partitioning during dust transportation. Particles were sampled with both a high volume sampler and high volume cascade impactor. In order to differentiate the episodic term results from nonepisodic conditions, sampling continued for two additional days after the episode.

\section{Materials and Methods}

2.1. Sampling. Sampling was conducted at the Yildiz Technical University, Davutpasa Campus in Istanbul, situated on the coordinates of $41^{\circ} 01^{\prime} 26^{\prime \prime} \mathrm{N}$ latitude and $28^{\circ} 53^{\prime} 16^{\prime \prime} \mathrm{E}$ longitude. The dust episode occurred on 1 February 2015. Ambient samples were taken on that day and the following two days.

Two devices were used for ambient sampling. A high volume air sampler (HVAS) was used to collect both particle and gaseous phase pollutants (Tecora ECHO HiVol). HVAS was equipped with a filter and cartridge holder. Ambient air was first drawn through glass fiber filter (GFF) and then passed through two polyurethane foams (PUFs) connected in a series, downstream of the glass fiber filter. The sampler was operated at $350 \mathrm{~L} \cdot \mathrm{min}^{-1}$ for 24 hours, which corresponds to approximately $500 \mathrm{~m}^{3}$ of ambient air sample. The device was calibrated before each sampling campaign. A six-stage high volume cascade impactor (HVCI) was used to collect and segregate ambient particles (Staplex). HVCI was operated at $1.1 \mathrm{~m}^{3} \cdot \mathrm{min}^{-1}$ for 24 hours. Total collected volume was approximately $1600 \mathrm{~m}^{3}$. Cut-off diameters of the HVCI were $7.2 \mu \mathrm{m}, 3 \mu \mathrm{m}, 1.5 \mu \mathrm{m}, 0.95 \mu \mathrm{m}$, and $0.49 \mu \mathrm{m}$ and the remaining particles were filtered through back-up filter. All filter materials were GFF.

Gravimetric measurements were conducted by AND GR202 analytical microbalance before and after the sampling process. Meteorological data were retrieved from the Davis Vantage Pro2 weather station located near the sampling devices at $10 \mathrm{~m}$ elevation.

\subsection{Sample Preparation}

2.2.1. Preparation of Filters and PUFs. PUFs were cleaned with $1: 1(\mathrm{v}: \mathrm{v})$ acetone : hexane for 24 hours before sampling. After cleaning, PUFs were dried at $70^{\circ} \mathrm{C}$ for 24 hours. Filters were wrapped with aluminum foil and baked at $450^{\circ} \mathrm{C}$ for six hours in a furnace to remove any organic residual. After the cleaning processes, filters and PUFs were cooled and kept in a desiccator.

2.2.2. Extraction. Prior to extraction, samples were spiked with PCB\#14, PCB\#65, PCB\#166, tetrachloro-m-xylene (TCMX), acenaphthene- $d_{10}$, phenanthrene- $d_{10}$, chrysene$\mathrm{d}_{12}$, and perylene- $\mathrm{d}_{12}$ surrogate solutions in order to determine recovery efficiencies of PCBs, OCPs, and PAHs. Concentrations of PCB, PAH, and OCP surrogates were $5 \mathrm{ng} \cdot \mathrm{mL}^{-1}, 10 \mathrm{ng} \cdot \mathrm{mL}^{-1}$, and $5 \mu \mathrm{g} \cdot \mathrm{mL}^{-1}$, respectively. Samples were extracted with a $1: 1(\mathrm{v}: \mathrm{v})$ acetone: hexane mixture. PUFs were Soxhlet extracted, whereas filters were ultrasonically extracted. The extraction duration of PUFs was 24 hours. The extraction time for filters was one hour. Filters were extracted with two equal aliquots in two sets of $30 \mathrm{~min}$. At first, filters were extracted at solvent mixture of $25 \mathrm{~mL}$ volume. When the extraction time was completed, $25 \mathrm{~mL}$ of the same solvent mixture was included and the extraction was continued for another 30 minutes. After extractions of the PUFs and filters were finished, their solvent volumes were reduced to $2 \mathrm{~mL}$ by rotary evaporator.

2.2.3. Clean-Up. Samples were then cleaned up and fractionated through a column of $3 \mathrm{~g}$ silicic acid (3\% water), $2 \mathrm{~g}$ neutral alumina (6\% water), and $2 \mathrm{~g} \mathrm{Na}_{2} \mathrm{SO}_{4}[29,30]$, which was prewashed with $20 \mathrm{~mL}$ of dichloromethane and $20 \mathrm{~mL}$ of petroleum ether, respectively. The sample in $2 \mathrm{~mL}$ of hexane was poured to the column and PCBs were eluted with $20 \mathrm{~mL}$ of petroleum ether. Then, PAHs and OCPs were eluted with $20 \mathrm{~mL}$ of dichloromethane. The solvent exchange procedure was applied to samples. Volumes of the samples were reduced to $2 \mathrm{~mL}$ under gentle nitrogen blow-down system and $15 \mathrm{~mL}$ of hexane was included. This step was repeated twice. The final extract was in hexane [31]. Samples including PCB were cleaned with $\mathrm{H}_{2} \mathrm{SO}_{4}$ and concentrated to $1 \mathrm{~mL}$ by stripping with pure nitrogen gas. Samples containing $\mathrm{OCP}$ and PAH compounds were only concentrated to $1 \mathrm{~mL}$ 
TABLE 1: Recovery percentage of PAH, PCB, and OCPs.

\begin{tabular}{lcccccccc}
\hline & PCB\#14 & PCB\#65 & PCB\#166 & TCMX & Acenaphthene- $\mathrm{d}_{10}$ & ${\text { Phenanthrene- } \mathrm{d}_{10}}{\text { Chrysene- } \mathrm{d}_{12}}_{\text {Perylene- } \mathrm{d}_{12}}$ \\
\hline PUFs & $79 \pm 16$ & $81 \pm 13$ & $99 \pm 2$ & $106 \pm 16$ & $65 \pm 19$ & $71 \pm 12$ & $79 \pm 13$ & $87 \pm 18$ \\
Filters & $73 \pm 20$ & $72 \pm 21$ & $91 \pm 30$ & $93 \pm 11$ & $63 \pm 22$ & $66 \pm 17$ & $73 \pm 14$ & $82 \pm 23$ \\
\hline
\end{tabular}

after solvent exchange. All samples were then placed in GC vials. At the last stage, internal standard mixtures of PCB\#30 and PCB\#121, pyrene- $\mathrm{d}_{10}$, and quintozene were included for volume correction.

2.2.4. GC Analysis. Quantification of PCBs and OCPs was performed by a GC-ECD system (PerkinElmer Clarus 500) equipped with a HP-5MS $(30 \mathrm{~m} \times 0.25 \mathrm{~mm} \times 0.25 \mu \mathrm{m})$, capillary column. The inlet temperature was $250^{\circ} \mathrm{C}$ and detector temperature was $320^{\circ} \mathrm{C}$. Ultrapure helium was used as the carrier at a flowrate of $1.2 \mathrm{~mL} \cdot \mathrm{min}^{-1}$. The makeup gas flowrate was $30 \mathrm{~mL} \cdot \mathrm{min}^{-1}$ for both PCBs and OCPs. For quantification of PCBs, the oven temperature was held at $70^{\circ} \mathrm{C}$ for two minutes and then raised to $150^{\circ} \mathrm{C}$ at a rate of $25^{\circ} \mathrm{C} \cdot \mathrm{min}^{-1}$, to $200^{\circ} \mathrm{C}$ at a rate of $3^{\circ} \mathrm{C} \cdot \mathrm{min}^{-1}$, and finally to $280^{\circ} \mathrm{C}$ at a rate of $8^{\circ} \mathrm{C} \cdot \mathrm{min}^{-1}$. The temperature was kept constant at $280^{\circ} \mathrm{C}$ for 10 minutes. The calibration was accomplished using seven standard solutions with concentrations ranging from $0.1 \mathrm{pg} \cdot \mu \mathrm{L}^{-1}$ to $30 \mathrm{pg} \cdot \mu \mathrm{L}^{-1}$. A total of 84 congeners, which are $\mathrm{PCB} \# 4 / 10, \mathrm{PCB} \# 7 / 9$, PCB\#6, PCB\#8/5, PCB\#19, PCB\#12/13, PCB\#18, PCB\#17/15, PCB\#16/32, РCB\#26, PCB\#31, РCB\#28, РCB\#33/53, РCB\#22, PCB\#45, РCB\#52, РCB\#47, РCB\#49/48, РCB\#44, РCB\#42/37, PCB\#71/64/41, РCB\#100, РCB\#74, РCB\#70/76, РCB\#66/95, PCB\#91， РCB\#56/60， РCB\#92， РCB\#84， РCB\#101/89, PCB\#99, PCB\#119, РCB\#83, РCB\#97, РCB\#87/81, PCB\#85, PCB\#77/110, PCB\#144/135, PCB\#114/149, PCB\#118, PCB\#123/131， PCB\#153， PCB\#132/105， PCB\#163/138, PCB\#126, PCB\#167/128, PCB\#174, PCB\#202/171/156, PCB\#172, PCB\#180, PCB\#200, РCB\#169, РCB\#170/190, PCB\#199, PCB\#207, PCB\#194, PCB\#205, and PCB\#206, were investigated. For quantification of OCPs, the oven temperature was held at $50^{\circ} \mathrm{C}$ for one minute and then raised to $170^{\circ} \mathrm{C}$ at a rate of $25^{\circ} \mathrm{C} \cdot \mathrm{min}^{-1}$, held 5.8 minutes at $170^{\circ} \mathrm{C}$, then raised to $300^{\circ} \mathrm{C}$ at a rate of $5^{\circ} \mathrm{C} \cdot \mathrm{min}^{-1}$, and finally held for two minutes at $300^{\circ} \mathrm{C}$. The calibration was accomplished using seven standard solutions with concentrations ranging from $0.5 \mathrm{pg} \cdot \mu \mathrm{L}^{-1}$ to $50 \mathrm{pg} \cdot \mu \mathrm{L}^{-1}$. Investigated OCPs were $\alpha$-, $\beta-, \gamma-$, and $\delta-\mathrm{HCH}$, heptachlor, aldrin, heptachlor-endoepoxide, alpha-endosulfan, dieldrin, 4.4'-DDE, endrin, beta-endosulfan, 4.4'-DDD, endrin aldehyde, endosulfan sulfate, $4.4^{\prime}$-DDT, endrin ketone, and methoxychlor.

Quantification of PAHs was executed by a PerkinElmer Clarus 500 gas chromatograph equipped with a Clarus 560 S Mass Spectrometer (MS) detector. HP-5MS, $30 \mathrm{~m} \times$ $0.25 \mathrm{~mm} \times 0.25 \mu \mathrm{m}$, was used as a capillary column. The inlet temperature of the GC oven was $250^{\circ} \mathrm{C}$. The mass inlet line temperature was kept at $180^{\circ} \mathrm{C}$ and the source temperature was kept at $200^{\circ} \mathrm{C}$. The oven temperature program was held at $50^{\circ} \mathrm{C}$ for one minute, then raised to $200^{\circ} \mathrm{C}$ at a rate of $25^{\circ} \mathrm{C} \cdot \mathrm{min}^{-1}$, and finally raised to $300^{\circ} \mathrm{C}$ at a rate of $8^{\circ} \mathrm{C} \cdot \mathrm{min}^{-1}$ and held for 5.5 minutes at $300^{\circ} \mathrm{C}$. The carrier gas was ultrapure helium at $1.0 \mathrm{~mL} \cdot \mathrm{min}^{-1}$ flow. Seven different levels of standards were prepared ranging between 0.05 and $10 \mathrm{ng} \cdot \mu \mathrm{L}^{-1}$ for calibration. Naphthalene $(\mathrm{Np})$, acenaphthylene (Acy), acenaphthene (Ace), fluorene (Flu), phenanthrene (Phe), anthracene (Ant), fluoranthene (Flt), pyrene $(\mathrm{Pyr})$, benz(a)anthracene $(\mathrm{BaA})$, chrysene $(\mathrm{Chr})$, benzo(b)fluoranthene $(\mathrm{BbF})$, benzo(k)fluoranthene $(\mathrm{BkF})$, benzo(a)pyrene (BaP), indeno(1,2,3-c,d)pyrene (IcdP), dibenz(a,h)anthracene (DahA), and benzo(g,h,i)perylene (BghiP) species were investigated within the samples.

Splitless injection was used for the entire samples. After each ten sample injections, stability was checked with the medium standard. The values of determination coefficients for distinct species were above 0.995 .

2.2.5. Quality Assurance/Quality Control. Glassware products, used in the laboratory, were washed with pure water, methanol, and dichloromethane, then dried, and covered with aluminum foil to protect them from contact with air [32]. Aluminum foils, used during the sample preparation and handling, were prebaked in the furnace and hexane rinsed.

Blank samples were taken with each data set. Limit of detection (LOD) for each pollutant was assumed as its blank signal plus three times its standard deviation [33, 34]. For PCB, PAH, or OCP species not detected in blank samples, LODs were based on their instrumental detection limit. All results were blank corrected. All recoveries were over 50\%, so no samples were excluded. Recovery values are given in Table 1.

\section{Results and Discussion}

3.1. Particle Matter Concentrations and Size Distribution. Ambient TSP concentrations ranged between 64 and $938 \mu \mathrm{g} \cdot \mathrm{m}^{-3}$. The highest concentration was observed on 1 February, during the dust transportation from the Saharan Desert. The MODIS image of this event is shown in Figure 1. Istanbul is located in the uppermost edge of the dust plume in Figure 1. Prevailing wind direction was SSW and wind speed was $7.8 \mathrm{~m} \cdot \mathrm{sec}^{-1}$. No precipitation was recorded on that day. On 2 February, TSP concentration was $78 \mu \mathrm{g} \cdot \mathrm{m}^{-3}$. Dust transportation was not observed, and, additionally, $14 \mathrm{~mm}$ precipitation was recorded. Wind direction and speed were SW and $5.0 \mathrm{~m} \cdot \mathrm{sec}^{-1}$, respectively. On 3 February, TSP concentration was $64 \mu \mathrm{g} \cdot \mathrm{m}^{-3}$. Wind direction and speed were SW and $4.72 \mathrm{~m} \cdot \mathrm{sec}^{-1}$, respectively. Precipitation amount was reduced to $2 \mathrm{~mm}$.

Several studies were conducted in Istanbul in terms of particulate matter pollution. Karaca et al. [35] reported $47.1 \mu \mathrm{g} \cdot \mathrm{m}^{-3}$ annual mean $\mathrm{PM}_{10}$ concentration. Koçak et al. [36] stated that the winter period, transitional period, 


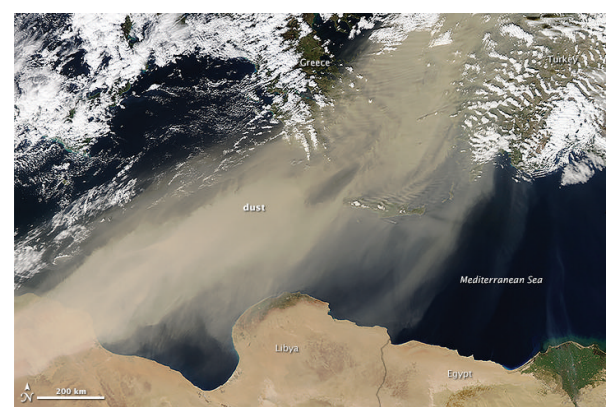

Figure 1: MODIS image of dust transportation from Saharan Desert.

and summer period $\mathrm{PM}_{10}$ concentrations were $44.5 \mu \mathrm{g} \cdot \mathrm{m}^{-3}$, $39.1 \mu \mathrm{g} \cdot \mathrm{m}^{-3}$, and $29.8 \mu \mathrm{g} \cdot \mathrm{m}^{-3}$, respectively. The reported average TSP concentrations at two urban sites in Istanbul were $101 \mu \mathrm{g} \cdot \mathrm{m}^{-3}$ and $152 \mu \mathrm{g} \cdot \mathrm{m}^{-3}$ [37]. Considering the previous studies, it could be inferred that ambient TSP concentration increased 10 times during the dust episode. Due to dry and wet deposition of particles, a sharp decrease in TSP concentrations was observed on the following two days. These concentrations were below the reported annual TSP concentrations. The precipitation event generated an additional force on concentration reduction.

In two distinct studies, it was reported that bimodal size distribution was observed in the Istanbul atmosphere [26, 38]. Sources of the particulate matter determine their size distribution. Relationship between adverse health effects of $\mathrm{PM}_{2.5--10}$ instead of $\mathrm{PM}_{2.5}$ during the Saharan dust transportation event was reported [39]. Particle size distributions of this study are shown in Figure 2.

This study revealed that particles retained on $3-7.2 \mu \mathrm{m}$ size fraction are highly enriched compared to nonepisodic period measurements. Bimodal size distribution was present. During the outbreak, mass median diameter (MMD) and geometric standard deviation $\left(\sigma_{g}\right)$ were $2.6 \mu \mathrm{m}$ and 6.1 , respectively. At the end of the episode, the dominance of $3 \mu \mathrm{m}$ sized particles decreased and again bimodal distribution was observed. Particles of $<0.49 \mu \mathrm{m}$ dominated the distribution. On 2 February, MMD and $\sigma_{g}$ were 1.0 and 6.9 , respectively. On 3 February, unimodal distribution was observed in the finest fraction. MMD and $\sigma_{g}$ were 0.9 and 9.2, respectively. log-probability plots of particle size distribution serves detailed information. Size distribution fractions achieved from HVCI cut-off diameters and, additionally, extracted $\mathrm{PM}_{10}, \mathrm{PM}_{4}, \mathrm{PM}_{2.5}$, and $\mathrm{PM}_{1}$ data from log-probability plots are given in Table 2 .

$\mathrm{PM}_{10}$ and $\mathrm{PM}_{4}$ are called thoracic and respirable fractions [40], respectively, and they are of great importance for epidemiological studies. Respirable fractions constituted 59.2\%, $76.8 \%$, and $74.4 \%$ of the particles for 1,2 , and 3 February, respectively. Although the respirable fraction is lower during the dust episode, the respirable PM amount is higher from other samples.

3.2. Gas and Particle PCB, PAH, and OCP Concentrations and Their Particle Size Distribution. Dust storms carry pollutants from different geographical locations. Sometimes
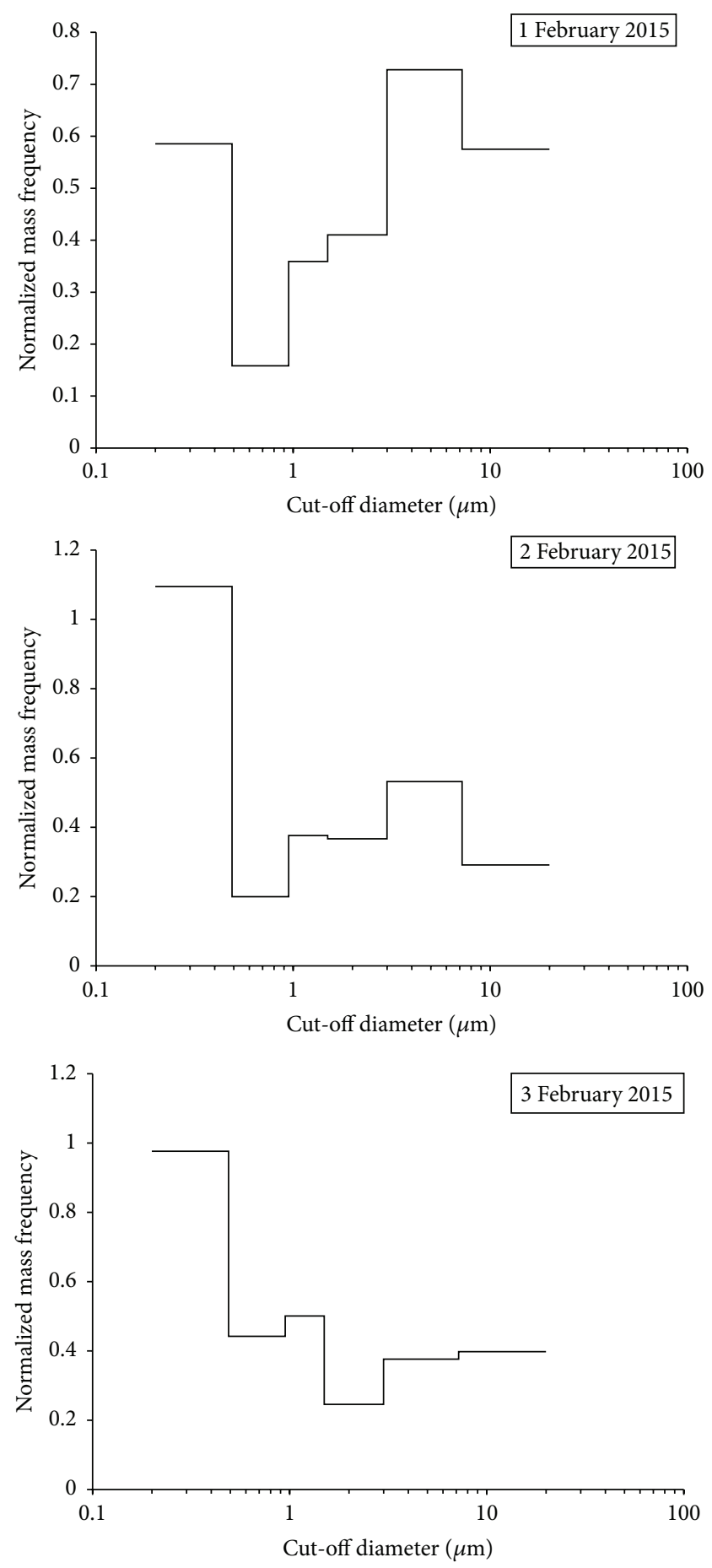

FIgURE 2: Ambient particulate matter size distribution.

these episodes cause increase in ambient POP concentrations. Ambient PCB concentrations increased about 2-3 times during Asian dust storm in northern Taiwan [41]. However, congener profiles of PCBs were consistent in the episode samples and nonepisode samples. In another study, in southern Taiwan and South China Sea, PCDD/F concentrations increased about 6-7 times during dust intrusion [42]. Congener profile was shifted in that incidence, probably suggesting the different source characteristics. 
TABLE 2: Different size fractions from log-probability plots.

\begin{tabular}{lccc}
\hline Cut-off diameter $(\mu \mathrm{m})$ & $\begin{array}{c}\text { 1 February } \\
\text { Cumulative mass less than }(\%)\end{array}$ & $\begin{array}{c}\text { 2 February } \\
\text { Cumulative mass less than }(\%)\end{array}$ & $\begin{array}{c}\text { 3 February } \\
\text { Cumulative mass less than }(\%)\end{array}$ \\
\hline 10 & 77.1 & 88.6 & 85.8 \\
7.2 & 74.5 & 87.1 & 82.4 \\
4 & 59.2 & 76.8 & 74.4 \\
3 & 52.9 & 72.1 & 68 \\
2.5 & 48.9 & 68.8 & 67.2 \\
1.5 & 34.5 & 55.8 & 60.7 \\
1 & 29.6 & 50.7 & 51.3 \\
0.95 & 27.3 & 48.4 & 50.7 \\
0.49 & 22.8 & 42.6 & 40 \\
\hline
\end{tabular}

Gas and particle phase pollutants on PCBs, PAHs, and OCPs during the sampling are presented in Table 3. PCBs were shown as homolog groups; their congener concentration was given in Supplementary Material Table 1, available online at http://dx.doi.org/10.1155/2016/7153286.

Total (gas + particle) PCB concentrations varied between $165 \mathrm{pg} \cdot \mathrm{m}^{-3}$ and $477 \mathrm{pg} \cdot \mathrm{m}^{-3}$. The highest concentration was observed during the dust episode. Twenty-one percent of the PCBs were found in the particle phase. On the following days this value decreased to $8 \%$ and $17.5 \%$, respectively. On average, $12 \%$ of PCB concentration is present in particles in the Istanbul atmosphere [43]. An excessive amount of observed TSP concentration contributed to the increase in particle phase PCBs during the episode. During the dust episode, Tri$\mathrm{CBs}$ were dominant in particle phase. However, penta-CBs were dominant in particles on the remaining days. Tri-CBs were dominantly found in Bursa and Bolu city atmospheres, which are close to Istanbul $[44,45]$. The second and third highest contribution occurred from tetra-CBs and pentaCBs from many of the samples. These homolog groups are predominantly found in soil samples $[32,46]$. Local sources seem to be the major contributor to congener profile during the nonepisodic period.

$\mathrm{PAH}$ concentrations varied from $83 \mathrm{ng} \cdot \mathrm{m}^{-3}$ to $244 \mathrm{ng} \cdot \mathrm{m}^{-3}$. Individual PAH concentrations were between n.d. and $7.0 \mathrm{ng} \cdot \mathrm{m}^{-3}$ in the particle phase and between n.d. and $113.9 \mathrm{ng} \cdot \mathrm{m}^{-3}$ in the gaseous phase. Ace was never detected during the three days in any of the samples. Phe and Flt were the most abundant compounds. Same dominant compounds were also previously reported in the Bursa atmosphere [47]. High molecular weight PAH compounds exhibited a tendency to be present in the particle phase. Averages of total PAH concentrations are higher than previously reported concentrations, covering more than an entire year, which were 100 and $84 \mathrm{ng} \cdot \mathrm{m}^{-3}$ at two different urban sites in Istanbul [37]. Average concentrations of PAHs for gas and particle phases were declared as $126.8 \mathrm{ng} \cdot \mathrm{m}^{-3}$ and $80 \mathrm{ng} \cdot \mathrm{m}^{-3}$, respectively, in Konya [48]. Higher results were reported in Zonguldak during the cold period, where gas and particle concentrations were reported as $293 \mathrm{ng} \cdot \mathrm{m}^{-3}$ and $188 \mathrm{ng} \cdot \mathrm{m}^{-3}$, respectively [49]. In this study, a higher amount of PAH concentration was detected in particles during the episode, whereas PAH concentrations were higher on the remaining days in the gaseous phase. Ambient temperature decreased gradually from 1 to 3 February as $16^{\circ} \mathrm{C}, 10^{\circ} \mathrm{C}$, and $8^{\circ} \mathrm{C}$, respectively. Thus, the need for heating on 1 February was the lowest. This could be one reason for decreased gaseous phase PAH concentrations. Additionally, 1 February 2015 fell on a Sunday. The traffic contribution is the least among other days. The diagnostic ratios of specific particle $\mathrm{PAH}$ species give clues about potential sources. In addition to source identification, the ratio of more reactive PAHs to less reactive PAHs is used to determine the degree of photochemical degradation and aging of the air mass [50]. Higher values of the $\mathrm{BaA} / \mathrm{BaP}$ ratio indicate relatively less association of PAH species with photochemical processes. Vardar et al. [13] reported average $\mathrm{BaA} / \mathrm{BaP}$ ratio of 1.39 and 0.72 , during heating and nonheating seasons, respectively. Highest value was observed during the dust episode (1.12). On the remaining days, the values were 0.33 and 0.15 , respectively. Dust plume hinders and reflects sunlight. Thus, a relatively high $\mathrm{BaA} / \mathrm{BaP}$ ratio occurred during dust transportation. A major local source around the sampling area is traffic. A $\mathrm{BaP} /$ BghiP ratio $>0.6$ indicates traffic sources; values $<0.6$ indicate nontraffic sources [51]. In particles, this ratio was 0.52 during the episode; however, it was 2.7 and 1.3 on 2 and 3 February, respectively. Traffic emissions are found to be prevailing on the weekdays. Nontraffic emissions were dominant during the episode.

Particle phase OCP concentrations varied between $57.4 \mathrm{pg} \cdot \mathrm{m}^{-3}$ and $160.6 \mathrm{pg} \cdot \mathrm{m}^{-3}$, while gas phase concentrations were between $321.6 \mathrm{pg} \cdot \mathrm{m}^{-3}$ and $571.4 \mathrm{pg} \cdot \mathrm{m}^{-3}$. The achieved results are in line with observed concentrations in Bursa [52]. However, results are lower than those in Konya, in the middle of Turkey [48]. The prevalence of OCPs was in the gaseous phase. The particle fraction of OCPs was between $9 \%$ and $22 \% . \beta-\mathrm{HCH}$ and heptachlor had the highest share. The lowest concentrations were detected during the dust incursion. Concentrations were mostly higher in the remaining days. Only $\beta$-endosulfan concentration was higher during the dust transportation. Long-range transportation does not seem to have an effect on controlling the atmospheric 
TABLE 3: Gas and particle phase PCB $\left(\mathrm{pg} \cdot \mathrm{m}^{-3}\right)$, PAH $\left(\mathrm{ng} \cdot \mathrm{m}^{-3}\right)$, and OCP $\left(\mathrm{pg} \cdot \mathrm{m}^{-3}\right)$ concentrations.

\begin{tabular}{|c|c|c|c|c|c|c|}
\hline & \multicolumn{2}{|c|}{1 February } & \multicolumn{2}{|c|}{2 February } & \multicolumn{2}{|c|}{3 February } \\
\hline & Particle & Gas & Particle & Gas & Particle & Gas \\
\hline $2-\mathrm{CBs}$ & 8.3 & 38.0 & 1.5 & 23.9 & 0.2 & 11.1 \\
\hline $3-\mathrm{CBs}$ & 27.6 & 118.6 & 3.3 & 59.7 & 2.1 & 51.0 \\
\hline 4-CBs & 24.0 & 96.0 & 1.3 & 45.7 & 2.9 & 69.0 \\
\hline $5-\mathrm{CBs}$ & 21.0 & 62.5 & 3.5 & 12.1 & 12.5 & 17.1 \\
\hline 6-CBs & 4.5 & 9.7 & 0.2 & 1.7 & 6.6 & 4.4 \\
\hline 7-CBs & 3.9 & 36.8 & - & 7.4 & 0.8 & 2.7 \\
\hline 8-CBs & 9.5 & 10.9 & 2.0 & 1.7 & 8.3 & 2.6 \\
\hline 9-CBs & 2.0 & 4.1 & 0.4 & 0.7 & 1.1 & 1.7 \\
\hline $\mathrm{Np}$ & 4.8 & 13.9 & 2.4 & 4.7 & 3.5 & 4.2 \\
\hline Acy & 0.6 & 1.4 & n.d. & 14.9 & 0.0 & 3.0 \\
\hline Ace & n.d. & n.d. & n.d. & n.d. & n.d. & n.d. \\
\hline Flu & 0.5 & 1.6 & n.d. & 9.8 & n.d. & 1.2 \\
\hline Phe & 7.1 & 12.6 & 1.1 & 77.8 & n.d. & 11.5 \\
\hline Ant & 3.9 & 1.4 & n.d. & 9.2 & n.d. & n.d. \\
\hline Flt & 4.9 & 4.8 & 0.7 & 30.9 & 0.8 & 113.9 \\
\hline Pyr & 4.0 & 2.8 & 0.7 & 28.0 & 0.1 & 16.7 \\
\hline $\mathrm{BaA}$ & 2.0 & 0.1 & 0.7 & 1.5 & 1.1 & 32.7 \\
\hline Chr & 2.3 & 0.1 & 1.9 & 3.3 & 1.2 & 26.8 \\
\hline $\mathrm{BbF}$ & n.d. & 0.1 & 3.9 & n.d. & 3.9 & 1.4 \\
\hline $\mathrm{BkF}$ & 4.6 & n.d. & 3.4 & n.d. & n.d. & n.d. \\
\hline $\mathrm{BaP}$ & 1.8 & n.d. & 2.2 & n.d. & 7.0 & 2.7 \\
\hline IcdP & 3.4 & n.d. & 0.8 & n.d. & 5.2 & 0.1 \\
\hline DahA & n.d. & n.d. & n.d. & n.d. & 5.1 & n.d. \\
\hline BghiP & 4.4 & n.d. & 1.1 & n.d. & 2.1 & n.d. \\
\hline$\alpha-\mathrm{HCH}$ & 2.3 & 6.7 & n.d. & 46.4 & n.d. & 21.0 \\
\hline$\beta-\mathrm{HCH}$ & 7.4 & 42.2 & 0.1 & 96.5 & 19.0 & 112.2 \\
\hline$\gamma-\mathrm{HCH}$ & 2.2 & 11.0 & 0.7 & 14.7 & 0.3 & 36.4 \\
\hline$\delta-\mathrm{HCH}$ & 1.2 & 23.0 & n.d. & 57.0 & 36.3 & 94.4 \\
\hline Heptachlor & 0.9 & 101.7 & 4.9 & 92.1 & 12.0 & 133.4 \\
\hline Aldrin & n.d. & 5.8 & 0.2 & 28.2 & n.d. & 12.8 \\
\hline Heptachlor-endo-epoxide & 9.9 & n.d. & n.d. & 8.4 & 0.4 & 44.0 \\
\hline$\alpha$-Endosulfan & 5.1 & n.d. & 7.2 & n.d. & n.d. & n.d. \\
\hline Dieldrin & 7.9 & 28.1 & 6.7 & 40.7 & n.d. & 35.7 \\
\hline $4.4^{\prime}-\mathrm{DDE}$ & 3.9 & n.d. & 1.2 & n.d. & 11.7 & 15.5 \\
\hline Endrin & 17.0 & n.d. & 2.6 & 12.1 & n.d. & n.d. \\
\hline$\beta$-Endosulfan & 3.1 & 29.4 & 14.2 & 13.2 & 0.9 & n.d. \\
\hline $4.4^{\prime}-\mathrm{DDD}$ & 0.5 & n.d. & 1.5 & 38.8 & 0.8 & 2.8 \\
\hline Endrin aldehyde & n.d. & 51.2 & 9.1 & 84.9 & 7.2 & 10.1 \\
\hline Endosulfan sulfate & 7.1 & 20.5 & 6.1 & 29.9 & 4.0 & 15.4 \\
\hline $4.4^{\prime}-\mathrm{DDT}$ & 0.8 & 2.1 & 2.8 & n.d. & 40.5 & 10.0 \\
\hline Endrin ketone & n.d. & n.d. & n.d. & n.d. & 12.7 & 15.6 \\
\hline Methoxychlor & n.d. & n.d. & 0.2 & 5.6 & 14.8 & 12.2 \\
\hline$\sum \mathrm{PCB}$ & 100.9 & 376.5 & 12.2 & 152.8 & 34.4 & 159.5 \\
\hline$\sum \mathrm{PAH}$ & 44.1 & 38.8 & 18.8 & 180.2 & 29.9 & 214.3 \\
\hline$\sum \mathrm{OCP}$ & 69.3 & 321.6 & 57.4 & 568.5 & 160.6 & 571.4 \\
\hline
\end{tabular}




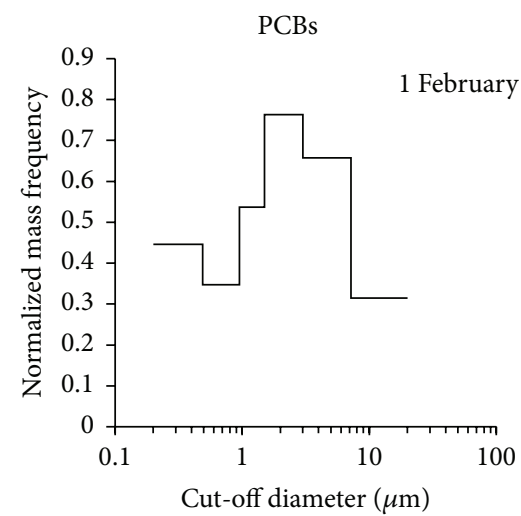

PAHs

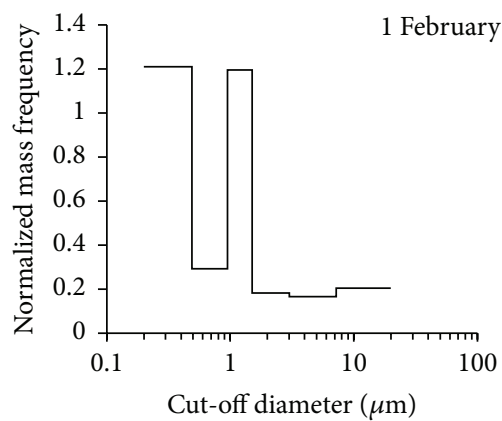

OCPs

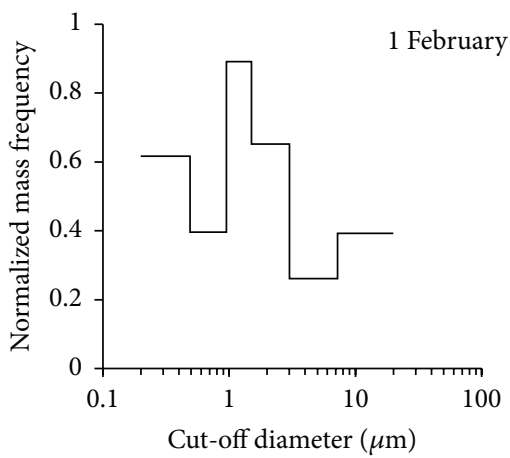

PCBs

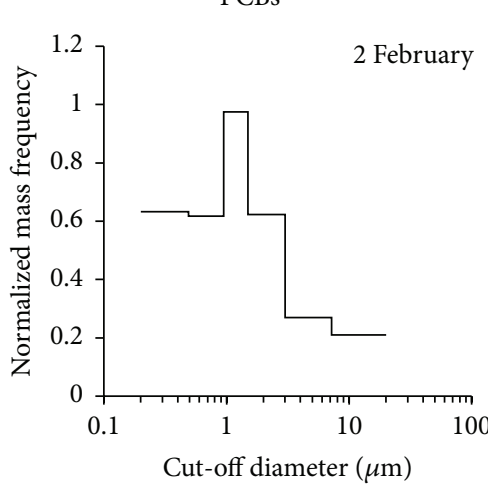

PAHs
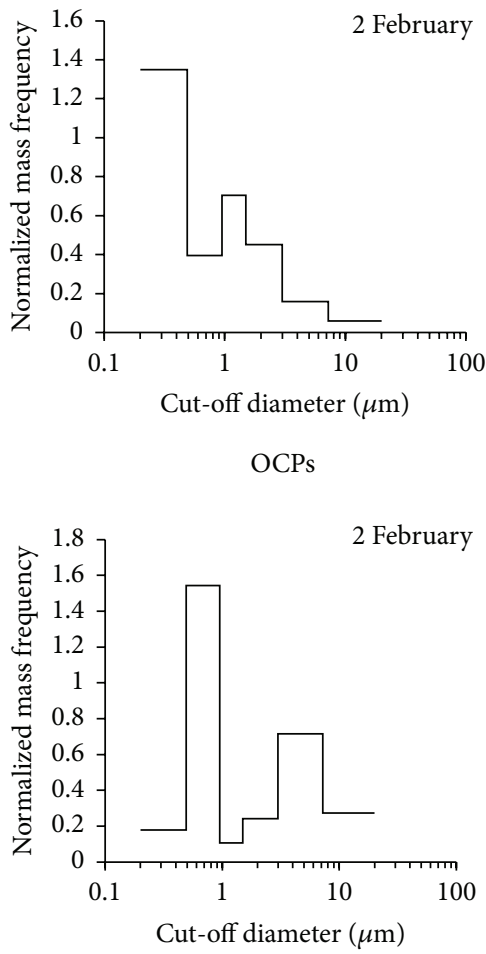

PCBs

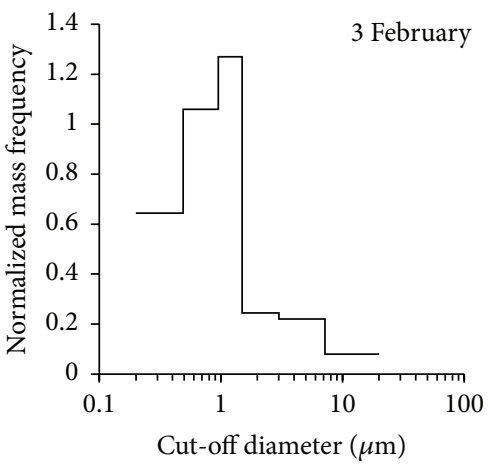

PAHs

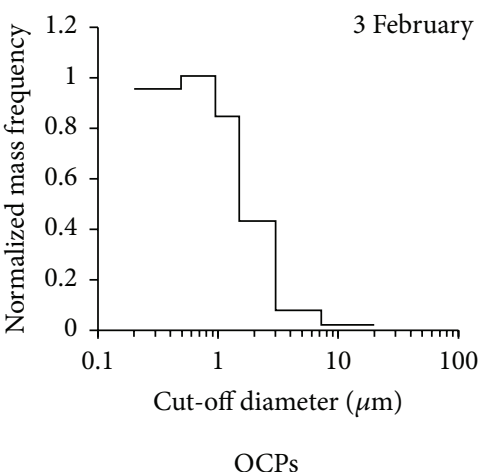

3 February

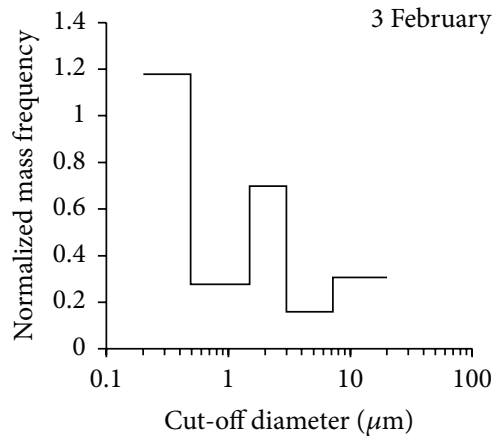

Figure 3: Size distribution of particle phase PCBs, PAHs, and OCPs.

concentrations of OCPs. One approach to evaluate the longrange transportation issue is the state of the $\alpha-\mathrm{HCH} / \gamma-\mathrm{HCH}$ ratio. When the ratio is $>1$, long-range transportation has an effect on ambient concentrations of $\mathrm{HCH}$ isomers [53]. Particle concentrations of the two isomers were only present on 1 February. The ratio was slightly over 1 . Prevailing $\mathrm{HCH}$ isomers did not significantly contribute to the long-range dust transportation.

Particle size distribution of PCBs, PAHs, and OCPs is given in Figure 3.

PCBs exhibited monomodal size distribution. This mode was observed at $1.5-3 \mu \mathrm{m}$ size fraction during the dust incursion. On the other days, the mode shifted to $0.95-1.5 \mu \mathrm{m}$ size fraction. MMDs of PCBs were $1.95 \mu \mathrm{m}, 1.14 \mu \mathrm{m}$, and
$0.85 \mu \mathrm{m}$ from 1 to 3 February, respectively. Size distribution of PCBs is in accordance with [12] except on 1 February. Dust transportation led to the deviation of the distribution of larger particles.

PAHs demonstrated bimodal distribution on 1 and 2 February and monomodal distribution on 3 February. The most dominant peaks were present at $<0.49 \mu \mathrm{m},<0.49 \mu \mathrm{m}$, and $0.49-0.95 \mu \mathrm{m}$ size fractions from 1 to 3 February, respectively. Second dominance was observed in $0.95-1.5 \mu \mathrm{m}$ size fractions. The MMDs of PAHs were $0.6 \mu \mathrm{m}, 0.5 \mu \mathrm{m}$, and $0.6 \mu \mathrm{m}$ from 1 to 3 February, respectively. The MMDs of PAHs were not significantly different from each other. Thus, it can be concluded that local source controls the atmospheric concentrations of PAHs. 
OCPs exhibited bimodal distribution in each of the samplings. Dominancy was not consistent; prevalence changed each day. On 1 February, the most dominant fraction was 0.95-1.5 $\mu \mathrm{m}$, while the second most dominant one was 1.5$3 \mu \mathrm{m}$. MMD was $1.5 \mu \mathrm{m}$. On 2 February, particles of $0.49-$ $0.95 \mu \mathrm{m}$ size fraction dominated the distribution. The second peak was observed at 3-7.2 $\mu \mathrm{m}$ size fraction. MMD was $1.7 \mu \mathrm{m}$ in this case. In this case MMD of OCP was larger than MMD of PM. This result suggests that after OCPs enter the air, they are cooled and condensed on larger particles by adsorption [54]. The same issue for OCPs was previously reported by [12]. On 3 February, dominancy was observed at $<0.49 \mu \mathrm{m}$ size fraction, while the second peak was at $1.5-3 \mu \mathrm{m}$ size fraction. MMD was $0.7 \mu \mathrm{m}$.

3.3. Gas/Particle Partitioning. Gas/particle partitioning is an indispensable process to explain the fate of the SVOCs in the atmosphere. Regression of $\log K_{P}$ versus $\log P_{L}^{0}$ is widely used for gas/particle partitioning calculations. $K_{P}$ is the experimental partitioning coefficient in $\mathrm{m}^{3} \cdot \mu \mathrm{g}^{-1}$ and $P_{L}^{0}$ is the subcooled vapor pressure in $\mathrm{Pa}$. The relation is given in

$$
\log K_{P}=\log \left(\frac{C_{P} / \text { TSP }}{C_{G}}\right)=m_{r} \log P_{L}^{0}+b_{r},
$$

where $C_{P}$ and $C_{G}$ are particle and gas phase SVOC concentrations, respectively. TSP is the total suspended particulate matter concentration in $\mu \mathrm{g} \cdot \mathrm{m}^{-3} \cdot m_{r}$ and $b_{r}$ are regression parameters. Regression parameters determine the degree of equilibrium. Pankow [55] stated that equilibrium is assumed to occur when $m_{r}$ is equal to -1 . However, in another study it was expressed that the equilibrium state can also be reached even though the slope parameter of the regression is different from -1 [56]. Sampling artifacts, fluctuations in TSP concentration and characteristics, the presence of nonexchangeable compounds on/in the particles, differences in the excess heat of desorption of the various compounds, and slow adsorption/desorption kinetics could result in shallow slopes other than $-1[30,57,58]$. Subcooled vapor pressure of organic pollutants is calculated according to (2). Experimental $m_{L}$ and $b_{L}$ values were gathered from Falconer and Bidleman [59] for PCBs, Odabasi et al. [60] for PAHs, and Cindoruk [52] for OCPs:

$$
\log P_{L}^{0}=\frac{m_{L}}{T}+b_{L}
$$

Regression plots are given in Figure 4.

Large variations among the regression slopes were observed. This is an expected case due to different meteorological conditions during the sampling. The shallowest slopes for each of the species are observed during the episodic conditions. This result suggests that the gas and particle phases are not in equilibrium. The increased TSP amount seems to be the reason for a nonequilibrium state. Additionally, transported particles from the Saharan Desert contain mineral dust, instead of organic content. That is why absorption capacity was reduced during the dust episode. The slope of PCB congeners varied between -0.44 and -0.04 ; intercept varied between -4.02 and -3.46 . Shallow slope was observed during the dust episode. The slopes observed on the remaining days are steeper than the previously reported mean value of -0.23 [43]. The slope of $\mathrm{PAH}$ species varied between -0.62 and -0.35 , whereas their intercepts varied between -5.35 and -3.49 . Slopes that are shallower than -0.6 are interpreted to be due to the absorption of compounds to organic matter in the particulate matter [61]. Vardar et al. [13] divided observed PAH gas/particle partitioning slopes according to seasons as heating and nonheating. The slopes of nonheating season ranged between -0.47 and -0.83 and those of heating season ranged between -0.62 and -0.82 . As stated earlier, air temperatures during the sampling period were $16^{\circ} \mathrm{C}, 10^{\circ} \mathrm{C}$, and $8^{\circ} \mathrm{C}$, respectively. Need for heating increased gradually from 1 to 3 February. This can be the additional factor for the steepest slope on 3 February for PAHs apart from other meteorological and particle related factors. The regression slopes of OCPs ranged from -0.17 to -0.78 and intercepts ranged from -4.20 to -4.69 . Except for the episodic period, slopes were relatively close to -1 . Cindoruk [52] determined OCP partitioning slopes to be in the vicinity of -0.5 in Bursa, which is located at approximately $100 \mathrm{~km}$ south of Istanbul. Bursa is closer to farming areas relative to Istanbul. It can be inferred that OCPs containing air masses were transported from further regions. Thus, the gas phase OCPs and particles had sufficient time to reach the equilibrium state.

\section{Conclusions}

In this study, sampling of ambient gas as well as particles was conducted by HVAS and HVCI on three consecutive days. The three days had different meteorological conditions. On the first day, dust transportation from Saharan Desert occurred. The next day, precipitation was observed and, on the third day, there were no significant extreme meteorological conditions or events. The aim of this study was to determine the gas and particle phase related concentrations and particle size distribution of aerosols and SVOCs during the dust storm and their variation after the storm. Ambient TSP was highly enriched during the dust transportation and PM size distribution was dominant at $3-7.2 \mu \mathrm{m}$ size fraction. On the other sampling days the dominancy was shifted to particles $<0.49 \mu \mathrm{m}$. Total PCB concentrations varied between $165 \mathrm{pg} \cdot \mathrm{m}^{-3}$ and $477 \mathrm{pg} \cdot \mathrm{m}^{-3}$. Highest PCB concentrations were observed during the dust episode. TriCBs were most abundant among the other investigated 7 homolog groups. PCBs exhibited monomodal size distribution with MMD varying between $0.85 \mu \mathrm{m}$ and $1.95 \mu \mathrm{m}$. $\mathrm{PAH}$ concentrations ranged between $83 \mathrm{ng} \cdot \mathrm{m}^{-3}$ and $244 \mathrm{ng} \cdot \mathrm{m}^{-3}$. The least concentrations were observed during the episode and particle concentrations were higher compared to gas phase during that sampling. PAHs exhibited bimodal particle size distribution on 1 February and 2 February at fractions of $<0.49$ and $0.95-1.5 \mu \mathrm{m}$. On the latter day, the dominancy was observed at $0.49-0.95 \mu \mathrm{m}$ size fraction. MMDs of PAHs were between $0.5 \mu \mathrm{m}$ and $0.6 \mu \mathrm{m}$. Total OCP concentrations 


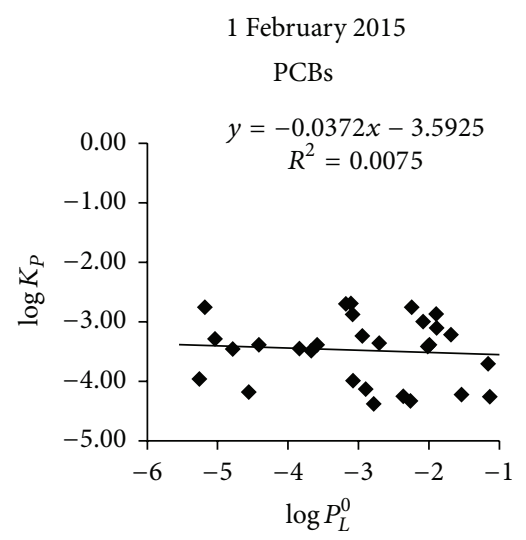

2 February 2015

PCBs

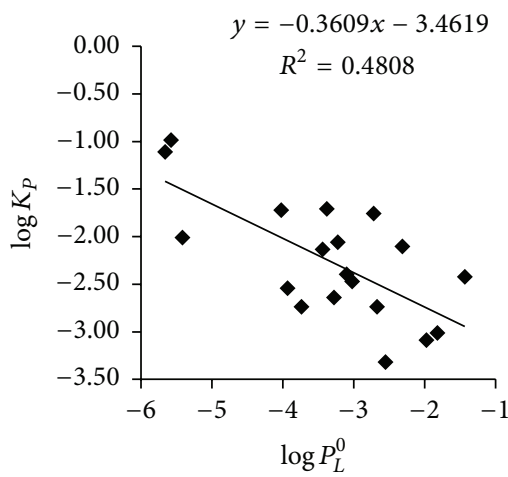

3 February 2015 PCBs

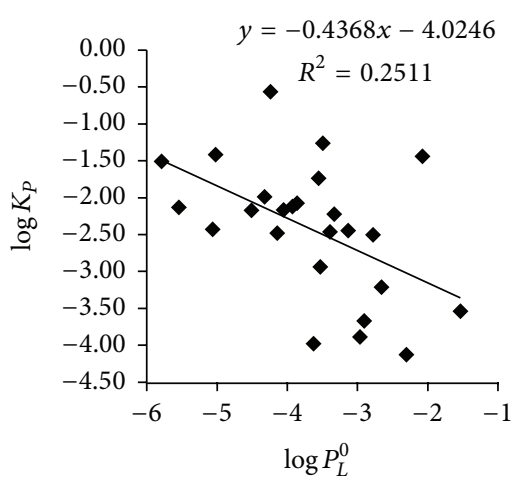

1 February 2015

PAHs

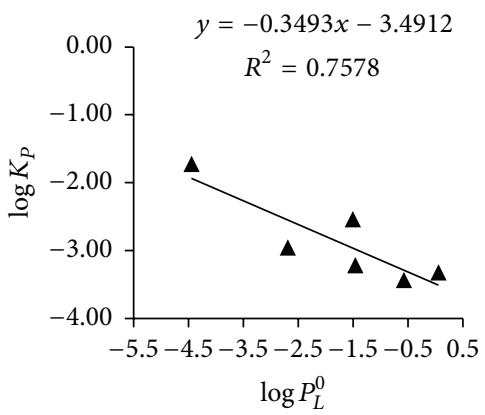

2 February 2015

PAHs

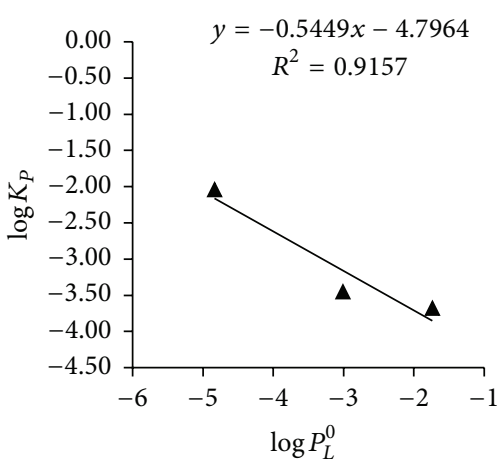

3 February 2015

PAHs

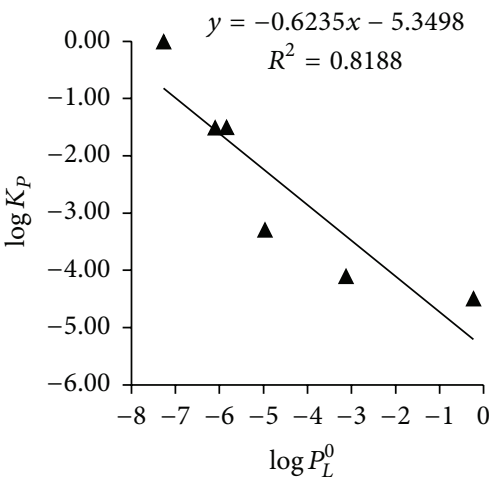

1 February 2015

OCPs

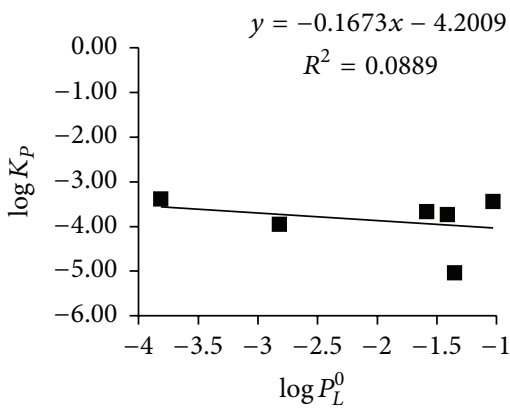

2 February 2015

OCPs

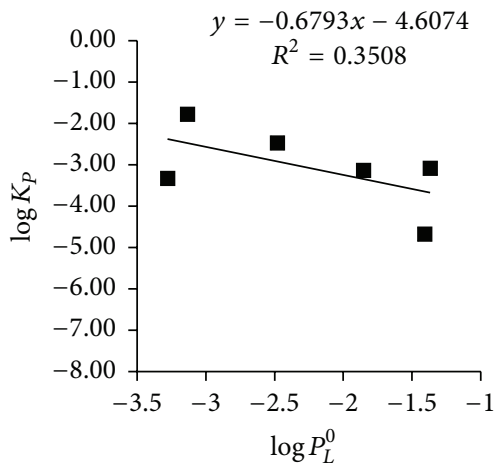

3 February 2015

OCPs

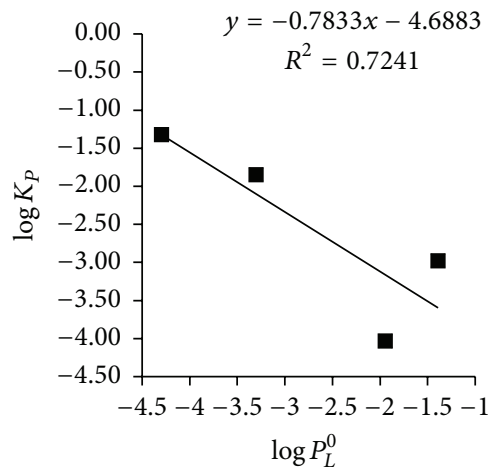

Figure 4: $\log K_{P}$ versus $\log P_{L}^{0}$ plots of PCBs, PAHs, and OCPs.

were between $391 \mathrm{pg} \cdot \mathrm{m}^{-3}$ and $732 \mathrm{pg} \cdot \mathrm{m}^{-3}$. The concentration gradually increased from 1 February to 3 February. OCPs were abundant in gaseous phase. They demonstrated bimodal particle size distribution during the entire sampling. Their MMDs ranged between $1.7 \mu \mathrm{m}$ and $0.7 \mu \mathrm{m}$. Gas/particle partitioning of PCBs, PAHs, and OCPs exhibited great differences during three days. During the episode gas and particle phases were far from the equilibrium state. On each proceeding day, the slope of the phases moved closer to equilibrium state.

\section{Competing Interests}

The author declares that there is no conflict of interests regarding the publication of this paper.

\section{Acknowledgments}

The author would like to acknowledge NASA for their permission to use the MODIS images in scientific studies and Didem Yolsal Kuzu, M.S., for her assistance during laboratory studies. 


\section{References}

[1] N. Künzli, R. Kaiser, S. Medina et al., "Public-health impact of outdoor and traffic-related air pollution: a European assessment," The Lancet, vol. 356, no. 9232, pp. 795-801, 2000.

[2] J. A. Bernstein, N. Alexis, C. Barnes et al., "Health effects of air pollution," Journal of Allergy and Clinical Immunology, vol. 114, no. 5, pp. 1116-1123, 2004.

[3] D. W. Dockery, C. A. Pope III, X. Xu et al., "An association between air pollution and mortality in six U.S. cities," The New England Journal of Medicine, vol. 329, no. 24, pp. 1753-1759, 1993.

[4] C. A. Pope III, R. T. Burnett, M. J. Thun et al., "Lung cancer, cardiopulmonary mortality, and long-term exposure to fine particulate air pollution," The Journal of the American Medical Association, vol. 287, no. 9, pp. 1132-1141, 2002.

[5] M. Jerrett, R. T. Burnett, R. Ma et al., "Spatial analysis of air pollution and mortality in Los Angeles," Epidemiology, vol. 16, no. 6, pp. 727-736, 2005.

[6] T. Yorifuji, E. Yamamoto, T. Tsuda, and N. Kawakami, "Health impact assessment of particulate matter in Tokyo, Japan," Archives of Environmental \& Occupational Health, vol. 60, no. 4, pp. 179-185, 2005.

[7] J. I. Halonen, T. Lanki, T. Yli-Tuomi, P. Tiittanen, M. Kulmala, and J. Pekkanen, "Particulate air pollution and acute cardiorespiratory hospital admissions and mortality among the elderly," Epidemiology, vol. 20, no. 1, pp. 143-153, 2009.

[8] Y. J. Kaufman, D. Tanré, and O. Boucher, "A satellite view of aerosols in the climate system," Nature, vol. 419, no. 6903, pp. 215-223, 2002.

[9] IPCC, "Aerosols, their direct and indirect effects," in Climate Change 2001: The Scientific Basis. Contribution of Working Group I to the Third Assessment Report of the Intergovernmental Panel on Climate Change, pp. 289-348, 2001.

[10] R. M. B. O. Duarte, C. L. Mieiro, A. Penetra, C. A. Pio, and A. C. Duarte, "Carbonaceous materials in size-segregated atmospheric aerosols from urban and coastal-rural areas at the Western European Coast," Atmospheric Research, vol. 90, no. 24, pp. 253-263, 2008.

[11] I. Salma, R. Ocskay, N. Raes, and W. Maenhaut, "Fine structure of mass size distributions in an urban environment," Atmospheric Environment, vol. 39, no. 29, pp. 5363-5374, 2005.

[12] L. P. Chrysikou, P. G. Gemenetzis, and C. A. Samara, "Wintertime size distribution of polycyclic aromatic hydrocarbons (PAHs), polychlorinated biphenyls (PCBs) and organochlorine pesticides (OCPs) in the urban environment: street- vs rooftoplevel measurements," Atmospheric Environment, vol. 43, no. 2, pp. 290-300, 2009.

[13] N. Vardar, F. Esen, and Y. Tasdemir, "Seasonal concentrations and partitioning of PAHs in a suburban site of Bursa, Turkey," Environmental Pollution, vol. 155, no. 2, pp. 298-307, 2008.

[14] B. Cetin, S. Yatkin, A. Bayram, and M. Odabasi, "Ambient concentrations and source apportionment of PCBs and trace elements around an industrial area in Izmir, Turkey," Chemosphere, vol. 69, no. 8, pp. 1267-1277, 2007.

[15] K. Breivik, A. Sweetman, J. M. Pacyna, and K. C. Jones, “Towards a global historical emission inventory for selected PCB congeners-a mass balance approach: 1. Global production and consumption," Science of the Total Environment, vol. 290, no. 13, pp. 181-198, 2002.
[16] M. Odabasi, A. Bayram, T. Elbir et al., "Electric arc furnaces for steel-making: hot spots for persistent organic pollutants," Environmental Science \& Technology, vol. 43, no. 14, pp. 52055211, 2009.

[17] G. Liu, M. Zheng, M. Cai et al., "Atmospheric emission of polychlorinated biphenyls from multiple industrial thermal processes," Chemosphere, vol. 90, no. 9, pp. 2453-2460, 2013.

[18] G. Liu, M. Zheng, W. Liu et al., "Atmospheric emission of PCDD/Fs, PCBs, hexachlorobenzene, and pentachlorobenzene from the coking industry," Environmental Science \& Technology, vol. 43, no. 24, pp. 9196-9201, 2009.

[19] F. van den Berg, R. Kubiak, W. G. Benjey et al., "Emission of pesticides into the air," Water, Air, and Soil Pollution, vol. 115, no. 1-4, pp. 195-218, 1999.

[20] A. Bozlaker, A. Muezzinoglu, and M. Odabasi, "Processes affecting the movement of organochlorine pesticides (OCPs) between soil and air in an industrial site in Turkey," Chemosphere, vol. 77, no. 9, pp. 1168-1176, 2009.

[21] C. Venkataraman, S. Thomas, and P. Kulkarni, "Size distributions of polycyclic aromatic hydrocarbons-gas/particle partitioning to urban aerosols," Journal of Aerosol Science, vol. 30, no. 6, pp. 759-770, 1999.

[22] A. Aulinger, V. Matthias, and M. Quante, "Introducing a partitioning mechanism for PAHs into the community multiscale air quality modeling system and its application to simulating the transport of benzo(a)pyrene over Europe," Journal of Applied Meteorology and Climatology, vol. 46, no. 11, pp. 1718-1730, 2007.

[23] H. Hung, P. Blanchard, C. J. Halsall et al., “Temporal and spatial variabilities of atmospheric polychlorinated biphenyls (PCBs), organochlorine (OC) pesticides and polycyclic aromatic hydrocarbons (PAHs) in the Canadian Arctic: results from a decade of monitoring," Science of the Total Environment, vol. 342, no. 1-3, pp. 119-144, 2005.

[24] F. Karaca and F. Camci, "Distant source contributions to PM10 profile evaluated by SOM based cluster analysis of air mass trajectory sets," Atmospheric Environment, vol. 44, no. 7, pp. 892-899, 2010.

[25] T. Kindap, A. Unal, S.-H. Chen, Y. Hu, M. T. Odman, and M. Karaca, "Long-range aerosol transport from Europe to Istanbul, Turkey," Atmospheric Environment, vol. 40, no. 19, pp. 35363547, 2006.

[26] S. L. Kuzu, A. Saral, S. Demir, G. Summak, and G. Demir, "A detailed investigation of ambient aerosol composition and size distribution in an urban atmosphere," Environmental Science and Pollution Research, vol. 20, no. 4, pp. 2556-2568, 2013.

[27] F. Karaca, I. Anil, and O. Alagha, "Long-range potential source contributions of episodic aerosol events to PM10 profile of a megacity," Atmospheric Environment, vol. 43, no. 36, pp. 57135722, 2009.

[28] I. Anil, K. Golcuk, and F. Karaca, "ATR-FTIR spectroscopic study of functional groups in aerosols: the contribution of a Saharan dust transport to urban atmosphere in Istanbul, Turkey," Water, Air, \& Soil Pollution, vol. 225, no. 3, pp. 1-14, 2014.

[29] R. L. Falconer, T. F. Bidleman, and W. E. Cotham, "Preferential sorption of non- and mono-ortho-polychlorinated biphenyls to urban aerosols," Environmental Science \& Technology, vol. 29, no. 6, pp. 1666-1673, 1995.

[30] Y. Tasdemir, N. Vardar, M. Odabasi, and T. M. Holsen, "Concentrations and gas/particle partitioning of PCBs in Chicago," Environmental Pollution, vol. 131, no. 1, pp. 35-44, 2004. 
[31] Y. Tasdemir and F. Esen, "Urban air PAHs: concentrations, temporal changes and gas/particle partitioning at a traffic site in Turkey," Atmospheric Research, vol. 84, no. 1, pp. 1-12, 2007.

[32] D. Yolsal, G. Salihoglu, and Y. Tasdemir, "Air-soil exchange of PCBs: levels and temporal variations at two sites in Turkey," Environmental Science and Pollution Research, vol. 21, no. 5, pp. 3920-3935, 2014.

[33] M. Odabasi, A. Sofuoglu, N. Vardar, Y. Tasdemir, and T. M. Holsen, "Measurement of dry deposition and air-water exchange of polycyclic aromatic hydrocarbons with the water surface sampler," Environmental Science \& Technology, vol. 33, no. 3, pp. 426-434, 1999.

[34] S. S. Cindoruk and Y. Tasdemir, "Characterization of gas/ particle concentrations and partitioning of polychlorinated biphenyls (PCBs) measured in an urban site of Turkey," Environmental Pollution, vol. 148, no. 1, pp. 325-333, 2007.

[35] F. Karaca, O. Alagha, and F. Ertürk, "Statistical characterization of atmospheric $\mathrm{PM}_{10}$ and $\mathrm{PM}_{2.5}$ concentrations at a nonimpacted suburban site of Istanbul, Turkey," Chemosphere, vol. 59, no. 8, pp. 1183-1190, 2005.

[36] M. Koçak, C. Theodosi, P. Zarmpas et al., "Particulate matter (PM10) in Istanbul: origin, source areas and potential impact on surrounding regions," Atmospheric Environment, vol. 45, no. 38, pp. 6891-6900, 2011.

[37] A. Hanedar, K. Alp, B. Kaynak, J. Baek, E. Avsar, and M. T. Odman, "Concentrations and sources of PAHs at three stations in Istanbul, Turkey," Atmospheric Research, vol. 99, no. 3-4, pp. 391-399, 2011.

[38] Ü. A. Şahin, K. Scherbakova, and B. Onat, "Size distribution and seasonal variation of airborne particulate matter in five areas in Istanbul, Turkey," Environmental Science and Pollution Research, vol. 19, no. 4, pp. 1198-1209, 2012.

[39] A. Tobías, L. Pérez, J. Díaz et al., "Short-term effects of particulate matter on total mortality during Saharan dust outbreaks: a case-crossover analysis in Madrid (Spain)," Science of the Total Environment, vol. 412-413, pp. 386-389, 2011.

[40] BSI, Workplace Atmospheres. Size Fraction Definitions for Measurement of Airborne Particles, British Standard Institute, London, UK, 1993.

[41] K. H. Chi, S. C. Hsu, S. H. Wang, and M. B. Chang, "Increases in ambient $\mathrm{PCDD} / \mathrm{F}$ and $\mathrm{PCB}$ concentrations in Northern Taiwan during an Asian dust storm episode," Science of the Total Environment, vol. 401, no. 1-3, pp. 100-108, 2008.

[42] N. T. Thuan, K. H. Chi, S.-H. Wang et al., "Atmospheric PCDD/F measurement in Taiwan and Southeast Asia during dongsha experiment," Atmospheric Environment, vol. 78, pp. 195-202, 2013.

[43] S. L. Kuzu, A. Saral, G. Summak, H. Çoltu, and S. Demir, "Ambient polychlorinated biphenyl levels and their evaluation in a metropolitan city," Science of the Total Environment, vol. 472, pp. 13-19, 2014.

[44] S. Yenisoy-Karaka, M. Öz, and E. O. Gaga, "Seasonal variation, sources, and gas/particle concentrations of PCBs and OCPs at high altitude suburban site in Western Black Sea Region of Turkey," Journal of Environmental Monitoring, vol. 14, no. 5, pp. 1365-1374, 2012.

[45] S. S. Cindoruk and Y. Tasdemir, "Atmospheric gas and particle phase concentrations of polychlorinated biphenyls (PCBs) in a suburban site of Bursa, Turkey," Environmental Forensics, vol. 9, no. 2-3, pp. 153-165, 2008.
[46] G. Salihoglu, N. K. Salihoglu, E. Aksoy, and Y. Tasdemir, "Spatial and temporal distribution of polychlorinated biphenyl (PCB) concentrations in soils of an industrialized city in Turkey," Journal of Environmental Management, vol. 92, no. 3, pp. 724732, 2011.

[47] A. Birgul and Y. Tasdemir, "Concentrations, gas-particle partitioning, and seasonal variations of polycyclic aromatic hydrocarbons at four sites in Turkey," Archives of Environmental Contamination and Toxicology, vol. 68, no. 1, pp. 46-63, 2015.

[48] S. Ozcan and M. E. Aydin, "Polycyclic aromatic hydrocarbons, polychlorinated biphenyls and organochlorine pesticides in urban air of Konya, Turkey," Atmospheric Research, vol. 93, no. 4, pp. 715-722, 2009.

[49] M. Akyüz and H. Çabuk, "Gas-particle partitioning and seasonal variation of polycyclic aromatic hydrocarbons in the atmosphere of Zonguldak, Turkey," Science of the Total Environment, vol. 408, no. 22, pp. 5550-5558, 2010.

[50] R. Lohmann, G. L. Northcott, and K. C. Jones, "Assessing the contribution of diffuse domestic burning as a source of PCDD/ Fs, PCBs, and PAHs to the U.K. Atmosphere," Environmental Science \& Technology, vol. 34, no. 14, pp. 2892-2899, 2000.

[51] A. Katsoyiannis, E. Terzi, and Q.-Y. Cai, "On the use of PAH molecular diagnostic ratios in sewage sludge for the understanding of the PAH sources. Is this use appropriate?" Chemosphere, vol. 69, no. 8, pp. 1337-1339, 2007.

[52] S. S. Cindoruk, "Atmospheric organochlorine pesticide (OCP) levels in a metropolitan city in Turkey," Chemosphere, vol. 82, no. 1, pp. 78-87, 2011.

[53] A. Sofuoglu, E. Cetin, S. S. Bozacioglu, G. D. Sener, and M. Odabasi, "Short-term variation in ambient concentrations and gas/particle partitioning of organochlorine pesticides in Izmir, Turkey," Atmospheric Environment, vol. 38, no. 27, pp. 44834493, 2004.

[54] S.-J. Chen, L.-T. Hsieh, and P.-S. Hwang, "Concentration, phase distribution, and size distribution of atmospheric polychlorinated biphenyls measured in southern Taiwan," Environment International, vol. 22, no. 4, pp. 411-423, 1996.

[55] J. F. Pankow, "An absorption-model of gas-particle partitioning of organic-compounds in the atmosphere," Atmospheric Environment, vol. 28, no. 2, pp. 185-188, 1994.

[56] M. F. Simcik, T. P. Franz, H. Zhang, and S. J. Eisenreich, "Gas-particle partitioning of PCBs and PAHs in the Chicago urban and adjacent coastal atmosphere: states of equilibrium," Environmental Science \& Technology, vol. 32, no. 2, pp. 251-257, 1998.

[57] M. Mandalakis, M. Tsapakis, A. Tsoga, and E. G. Stephanou, "Gas-particle concentrations and distribution of aliphatic hydrocarbons, PAHs, PCBs and PCDD/Fs in the atmosphere of Athens (Greece)," Atmospheric Environment, vol. 36, no. 25, pp. 4023-4035, 2002.

[58] J. F. Pankow and T. F. Bidleman, "Interdependence of the slopes and intercepts from log-log correlations of measured gasparticle paritioning and vapor pressure-I. theory and analysis of available data," Atmospheric Environment Part A, General Topics, vol. 26, no. 6, pp. 1071-1080, 1992.

[59] R. L. Falconer and T. F. Bidleman, "Vapor pressures and predicted particle/gas distributions of polychlorinated biphenyl congeners as functions of temperature and ortho-chlorine substitution," Atmospheric Environment, vol. 28, no. 3, pp. 547$554,1994$. 
[60] M. Odabasi, E. Cetin, and A. Sofuoglu, "Determination of octanol-air partition coefficients and supercooled liquid vapor pressures of PAHs as a function of temperature: application to gas-particle partitioning in an urban atmosphere," Atmospheric Environment, vol. 40, no. 34, pp. 6615-6625, 2006.

[61] K.-U. Goss and R. P. Schwarzenbach, "Gas/solid and gas/liquid partitioning of organic compounds: critical evaluation of the interpretation of equilibrium constants," Environmental Science and Technology, vol. 32, no. 14, pp. 2025-2032, 1998. 

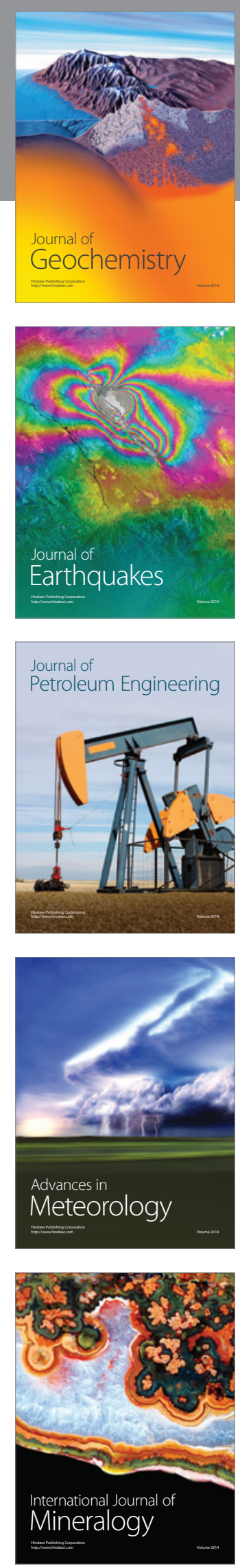
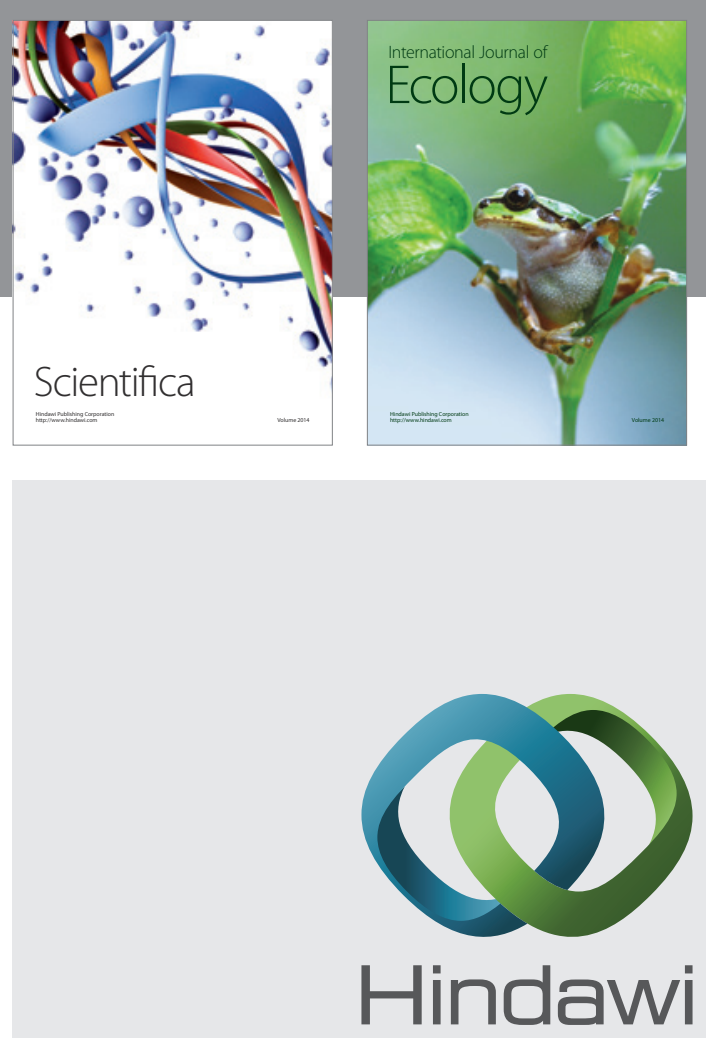

Submit your manuscripts at

http://www.hindawi.com
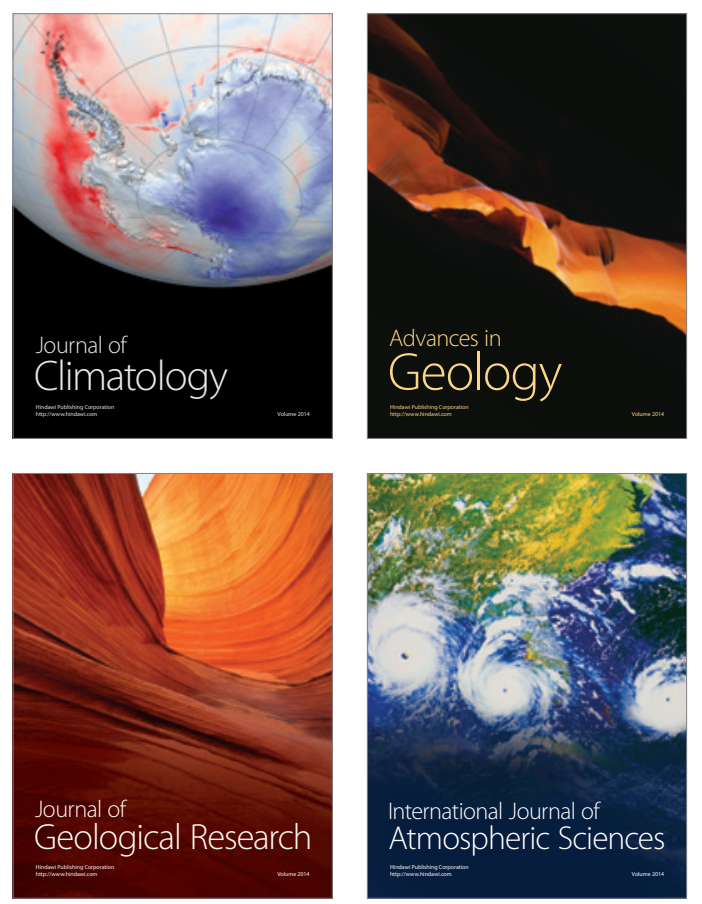

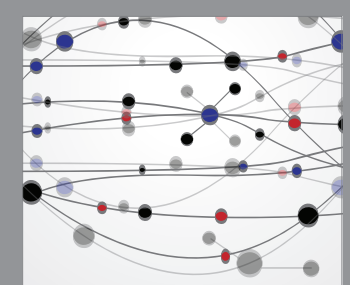

The Scientific

\section{World Journal}
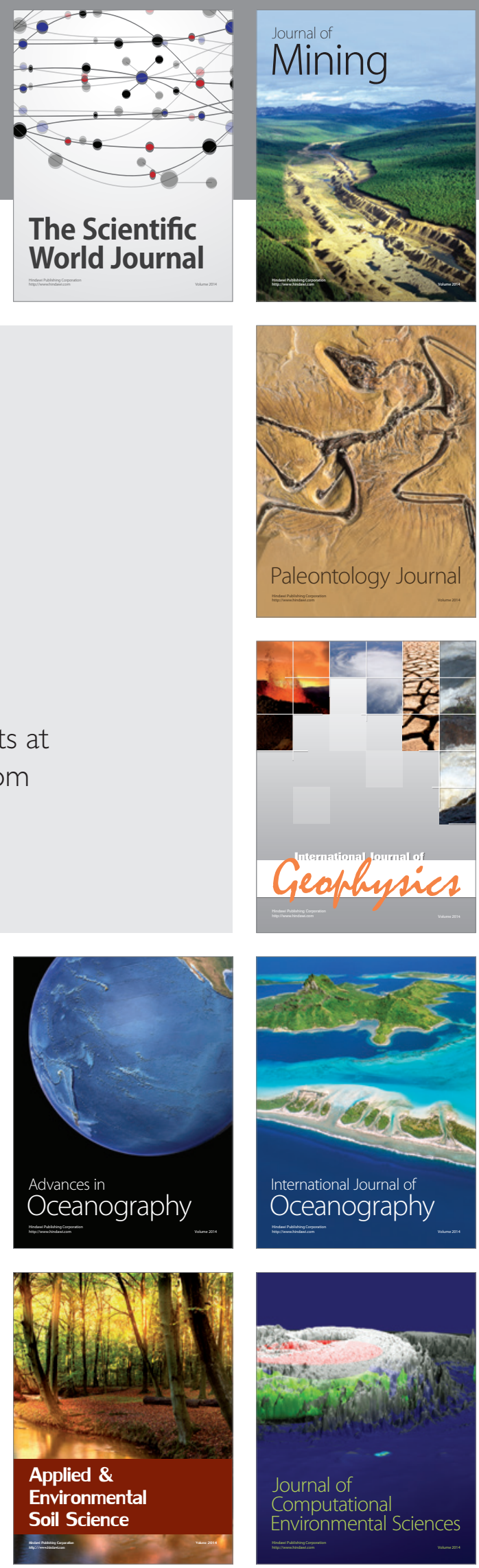